\title{
Üniversite Öğrencilerinin Hedonistik Eğilimleri ve Duygusal İstikrarlılıklarının Alışveriş Bağımlılıklarına Etkisinde Finansal Öz Yetkinliklerinin Rolü
}

\author{
DOI: 10.26466/opus.588082 \\ * \\ Esra Özkan Pir * \\ *Dr. Öğr.Üyesi,Erzincan Binali Yıldırım Üniversitesi, Erzincan/ Türkiye \\ E-Posta: esraozkanpir@gmail.com \\ ORCID:0000-0002-1271-7397
}

Öz

Pazarlama disiplininin önemli amaçlarından biri, bireyin satın alma sürecini tüm boyutlarıyla çözümleyebilmektir. Rasyonelliğin mutlak hâkimiyetinden çıkan satın alma ve alı̧̧veriş kavramına dair bakış açısı, zamanla değiş̧im göstermiştir. Geçmişte bireyi satın almaya iten neden "gereksinim" iken, günümüzde bu güdüler "istek", "eğlence" ve "deneyim" gibi duygusal yoğunluklu kavramlara dönüşmüştür, hatta bazı kişiler için satın alma hayatlarında istedikleri yere ulaşmak adına bir araç değil amaç haline gelmiştir denilebilir. Böylece, toplumda genel olarak işleyen ve örnek oluşturduğu düşünülen satın alma davranışın inceleyen tüketici davranışı disiplini, aynı zamanda normallikten sapan ve aşırı sayılabilecek belirli satın alma davranış şekillerini araştırarak, bireyi anlamayı bütünsel hale getirmiştir. Bu çalışmanın amacı Üniversite öğrencilerinin alışveriş bağımlılı̆̆ını ölçülmesinde hedonistik eğilimleri ve duygusal istikrarlllıklarının etkisinin ölçülmesinde finansal öz yetkinliklerinin aracı etkisinin incelenmesidir. Bu araştırmayı gerçekleştirebilmek adına Erzincan Binali Yıldırım Üniversitesinde eğitim gören 598 öğrenciye anket uygulanmıştır. Anket çalışması neticesinde elde edilen veriler SPSS paket programı kullanılarak analiz edilmiş ve sonuçları yorumlanmıştır. Çalışma sonucunda kadın katılımcıların erkek katılımcılara göre alışveriş bağımlılıklarının daha fazla olduğu, gelir durumu arttıkça katılımcıları alı̧̧veriş bağımlllıklarının da arttığı ve'duygusal istikrar' ile 'hedonik tüketim' değiş̧kenlerinin 'alışveriş bağımlılığı' üzerinde etkisi olduğu ve bu etkiye 'finansal öz yetkinlik' isimli değ̌ş̧kenin aracı etkisinin olduğu tespit edilmiştir.

Anahtar Kelimeler: Alışveriş bağımlılı̆̆ı, Hedonistik eğilim, Duygusal İstikrar, Finansal öz yetkinlik 


\title{
The Role of Financial Self-Efficacy in the Effect of Hedonistic Tendencies and Emotional Stability on Shopping Addiction of University Students
}

\begin{abstract}
One of the important objectives of marketing discipline is to analyze the purchasing process of the individual in all its dimensions. The point of view of the concept of buying and shopping, which emerges from the absolute dominance of rationality, has changed over time. In the past, the need to buy the individual was the reason, but nowadays, these motives have turned into emotional-intensive concepts such as desire, entertainment and experience. Thus, the discipline of consumer behavior, which generally operates in society and examines the purchase behavior thought to be exemplary, has also made understanding of the individual holistic by investigating certain forms of purchasing behavior that deviate from normality and can be considered excessive. The aim of this study is to investigate the mediator effect of financial self-efficacy in measuring the effect of hedonistic tendencies and emotional stability of university students in measuring shopping addiction.Research was conducted in 598 students at Binali Yaldirm University in Erzincan. The data obtained from the survey were analyzed using SPSS 21 package program and the results were interpreted.As a result of the study, it was observed that female participants had more shopping addictionthan male participants, and as the income level increased, participants' shopping addictions increased as well. And emotional stability and hedonic consumption variables have an effect on shopping addiction and financial self-efficacy has mediated role between those relationship.
\end{abstract}

Keywords: Shopping addiction, Hedonistic tendency, Emotional stability, Financial self-efficacy 


\section{Giriş}

1980"lerden sonraki yazın incelendiğinde, özellikle 1996-2004 yılları arasında, anormal satın alma davranışı kapsamında "satın alma bağımlılığı" olgusu akademik yayınlarda konu başlığı olarak göze çarpmaktadır (Dittmar,2004,s.431). Satın alma bağımlılığına geniş bir çerçeveden bakıldığında, bu konunun tepkisel tüketim, aşırı tüketim gibi tüketime dair istisnai davranışlar başlığı altında incelendiği görülmektedir. Bazı araştırmacılar, bu tüketim davranışlarını kompulsif bozukluk olarak tanımlarken, bir diğer kesim bunu bağımlılık olarak nitelendirmektedir. Kompulsif yaklaşım, genel anlamda, engellenemeyen dürtülerinin, bireyi istem dışı hareket etmesine neden olması sürecine ilişkindir. Bağımlılık ise, normal bir davranışın patolojik bir alışkanlık olarak kişinin hayatında yer etmesi olarak açiklanmaktadır (Desmond,2003,s.392). Literatür incelendiğinde alışveriş bağımlılığı ve satın alma bağımlılığının birbirlerinin yerine kullanılabildiklerini görmekteyiz. Ancak unutulmamalıdır ki, alışveriş yapma eylemi genellikle satın almayla sonlansa da, bir ürün/hizmetin satın alınması şart değildir. Alışveriş yapmak güncel tüketici için adeta, günlük hayatın bir parçası, bir ritüeli haline gelmiştir. Tüketici bir şey satın almasa da bu tüketicinin alışveriş ortamında harcadığı zaman, edindiği bilgi/deneyim ya da yaşadığı duygular gerçeğini değiştirmemektedir. Bu doğrultuda, satın alma bağımlılığı yerine alışveriş bağımlılı̆̆ı terimi kullanılabilmektedir.

Çalışmanın ana amacı, alışveriş bağımlılığına etki ettiği düşünülen bireylerin hedonistik eğilimleri, duygusal istikrarlılıkları ve finansal öz yetkinlikleri gibi etkenler araştırılmıştır, bu da bağımlılık gibi güçlü ve normalden sapan bir kavramı farklı açılardan açıklanabilmesine olanak vermiştir. Çalışmada alışveriş bağımlılığına etki eden faktörler ele alınırken bireylerin finansal öz yetkinlikleri aracı değişken olarak kabul edilmiştir. Bu doğrultuda ele alınan çalışma, dört ana bölümden oluşmaktadır. İlk bölüm olan giriş kısmında, konuya dair kısa bilgi verilerek, araştırmanın amacı ve kapsamı açıklanmıştır. İkinci bölüm olan kavramsal çerçeve kısmında alışveriş bağımlılığına dair tanımlar, hedonistik eğilim, duygusal istikrar, finansal öz yetkinlik kavramları detaylandırılarak açıklanmıştır. Üçüncü bölümde ise üniversite öğrencilerinde hedonistik eğilim ve duygusal istikrarlılıklarının alışveriş bağımlılıklarına etkisinde 
finansal öz yetkinliklerinin aracı etkisini ölçmeye yönelik hangi yöntemlerin izlendiği aktarılmıştır. Araştırmanın dördüncü bölümünde ise yap1lan analizler neticesinde elde edilen bulgulara yer verilmiştir.

\section{Araştırmanın Kavramsal Çerçevesi}

\section{Alışveriş Bă̆ımlılı̆̆ı}

Tüketici davranışı literatürünü alışveriş bağımlılığı kavramıyla tanıştıran, Faber ve diğerlerinin 1987 deki çalışmasıdır. En yalın anlamda alışveriş bağımlılı̆̆ı; negatif durumlara ya da duygulara cevap olarak geliştirilen aşırı, kontrol edilemeyen, zaman alan ve süreklilik arz eden bir satın alma eylemidir ve çoğunlukla da sosyal ve finansal problemlerle neticelenir (Faber ve O'Guinn,1988; McElroy vd.,1994; Kyrios vd., 2004, s.241). D"astous ve Tremblay(1989) ise bu davranış biçimini genel satın alma dürtüsünün ekstrem durumu olarak nitelendirmiştir. Pazarlama ve psikoloji dünyasında üzerinde durulan bu "aşırı davranış" olan alışveriş bağımlılığının üç temel bileşeni; tüketicinin önüne geçemediği satın alma isteği, satın alma sürecinde yaşadığı kontrol kaybı ve yaşanılan sosyal, mesleki ve finansal olumsuzluklara rağmen satın almaya devam edilmesi olarak özetlenebilir (Dittmar vd.,2007).

Black (2001) satın alma bağımlılığında fazla ya da kontrolü mümkün olmayan kaygı ve ihtiyaç duyulmayan objelerin anlık ya da kompulsif şekilde satın alım isteği üzerinde durmuştur. Hirschman ise 1992 yılında yaptığı çalışmada satın alma bağımlılı̆̆ının yetersizlik duygusundan kaynaklandığını öne sürerek, bunu bir bağımlılık süreci ya da bağımlılık deneyimi olarak tanımlamıştır.

Kompulsif alışveriş, bazen kasitsız ve tekrarlanan, yaygın bir problemdir. Sorunun yüksek yaygınlığı ve diğer bağımlılıklara olan güçlü benzerlikleri göz önüne alındığında, alışveriş potansiyel olarak bağımlılık yaratan bir davranış olarak tanımlanabilmektedir (Hartston,2012,s.67).

Genellikle, ürünler bireysel gereksinimleri karşılamak ve kişisel memnuniyeti artırmak için satın alınır. Ancak, sınırlandırılmamış dürtü satın alma içeren sınırsız satın alma, bireyleri, aileleri ve toplulukları tahrip edebilir (Sohn, ve Choi, 2014,s.244). Kompulsif satın alma bozuk- 
luğu (oniomania), gün geçtikçe artan ciddi bir sorundur. Tüketici pazarı sürekli geliştiğinden, tüccarlar giderek tüketicilerin daha fazla satın alma şeklini etkileyebilecek şekillere odaklanmıştır. Bu indirim, promosyon paketleri, ikramiye, sadakat ödülleri vb. ile yapılabilmektedir (Simion, 2018,s.2).

Zorunlu satın alımın diğer karakteristikleri, satın alma dürtüsünden ziyade sıklıkla satın alma dürtüsünü içerir. Satın alma ihtiyacını rasyonelleştirmek, hatta satın almaya karşı karar vermek, uygun olmayan ve / veya kişisel sıkıntılara yol açabilecek gereksiz eşyaları satın almak ailevi veya sosyal ilişkilerin, mesleki zorlukların ve finansal veya yasal sorunların göstergesidir (O'Guinn ve Faber, 1989; Faber ve O'Guinn, 1992)..

Literatürde alışveriş bağımlılığı konu edilen güncel araştırmalara bakıldığında; Chinomona(2013) yaptığı çalışmada alışveriş bağımlılı̆̆ını, marka deneyimi, marka tatmini, marka güveni, marka bağlılığ ile ilişkilendirmiş ve yapılan araştırma sonucunda marka güveni, marka tatmini ve marka bağ lılığı ile alışveriş bağımlılığı arasında pozitif ilişki saptanmiştır.

Rao (2013) yaptığı çalışmada alışveriş bağımlılı̆̆ını, özgüven ile ilişkilendirmiş ve yapılan araştırma sonucunda özgüven ve alışveriş bağımlılığ 1 arasında negatif bir ilişki olduğu ortaya konmuştur

Mikołajczak-Degrauwe, Brengman, Wauters ve Rossi (2012) yaptıkları çalışmada alışveriş bağımlılığını açıklık, dışa dönüklük, uyumluluk, duygusal denge, sorumluluk ile ilişkilendirip araştırma sonucunda alışveriş bağımlıları ve diğer tüketiciler arasında dışa dönüklük, uyumluluk, duygusal denge ve açıklık ile anlamlı farklılık belirlenmiştir.

Lo ve Harvey (2011) yaptıkları çalışmada alışveriş bağımlılığını kredi kartı kullanımı, aşırı harcama ile ilişkilendirip neticesinde alışveriş bağımlıları kredi kartları nedeniyle(kısmi ilişki) aşırı satın alım yaparlar, fiyattan etkilenmezler ayrıca alışveriş bağımlıları bütçeleri konusunda daha az bilinçlidir ve alışverişten daha fazla zevk alırlar sonucuna ulaşmışlardır.

Palan, Morrow, Trapp II ve Blackburn (2011) özgüven, güç-prestij, risk algılama, kredi kartının yanlış kullanımı ile ilişkilendirip, yapılan çalışma da genel model uyumu çok iyi sonuç verirken, güç-prestij değiş̧keni ile doğrudan ve dolaylı etki belirlenirken, özgüven ve risk alma ile alışveriş 
bağımlılığı arasında ilişki bulunamamıştır. Ayrıca kredi kartı yanlış kullanımının da aracı değişken olduğu doğrulanamamıştır.

Saleem, Abideen ve Latif (2010) yaptıkları çalışmada alışveriş bağımlılığını yaş, harcama eğilimi, alışverişe ve harcamaya dair duygular, kompulsif harcama dürtüsü, işlevsiz harcama, satın alım sonrası suçluluk ile ilişkilendirip araştırma sonucunda erkek ve kadınlar arasında alışveriş bağımlılı̆̆ının anlamlı biçimde farklılaştığını tespit etmişlerdir. Alışveriş bağımlılığı ve yaş arasında negatif ancak kompulsif harcama, harcama eğilimi, alışverişe ve harcamaya dair duygular, işlevsiz harcama, satın alım sonrası suçluluk arasında pozitif ilişki bulunmuştur.

Johnson ve Attmann(2009) yaptıkları çalışmada alışveriş bağımlılığını duygusal dengesizlik, moda ilgisi, materyalizm ile ilişkilendirip neticesinde alışveriş bağımlılığı ile duygusal dengesizlik ve moda ilgisi arasında anlamlı ilişki bulunurken; materyalizm ve alışveriş bağımlılı̆̆ı arasında ilişki saptanamamıştır.

\section{Hedonistik Ĕ̈ilim}

Ekonomide, tüketicinin karar verme süreci rasyonel olarak algılanırken; pazarlama disiplininde, özellikle 1980 sonrası güncel çalışmalarda bu mekanizmanın salt rasyonellikle açıklanamayacağına inanılarak duyguların ve hislerin de bu süreçte etkili olduğu belirlenmiştir. Pazarlama literatürüne "hedonik tüketim" kavramı, ilk defa Hirschman ve Holbrook un 1982"de yaptıklarıçalışmada yer almıştır. Yazarlar, bu soyut değerlerin satın alma üzerindeki etkisinin önemine dikkat çekerek; bireyin tüketim deneyimine yön veren öğeleri duyuları, fantezi dünyasını ve duyguları yani "hedonik öğeler" olarak ifade etmiştir (Hirschman ve Holbrook,1982, s.94).

Hedonistik tüketim davranışı aslında tüketicinin plansız satın alma davranışı gerçekleştirmesidir. Plansız satın almanın temelinde tüketicilerde haz ve heyecan söz konusudur. Hedonistik tüketim süreci tüketicinin zihninde oluşan bir tasarım olup marka değerleri ve çağrışımları, satın alımı gerçekleştiren bireyin ruh halini ve duygusal tasarımını etkiler (Rook ve Fisher,1995,s.305). Deneyime açıklık eğilimi yüksek olan bireyler, kendilerini tanımlamada bağımsızlığı ve kendine özgü olmayı 
vurgulamaktadırlar ayrıca çeşitliliği tek tip olmaya da tercih etmektedirler (Yilmaz, 2019, s.172).

1986'da Sproles ve Kendall'ın oluşturduğu“Tüketici Tarzları Envanteri"nde yer alan tüketicilerin karar verme biçimini oluşturan en temel sekiz zihinsel özellikten biri olan "Hedonistik Tüketim Bilinci" ya da yazarların bir diğer deyişiyle "Eğlence Merkezlilik", alışverişi daha çok eğlence, boş vakitleri değerlendirme, sosyal paylaşım ve hoş bir aktivite olarak görmektir (Sproles ve Kendall, 1986,s.121).

Tonita Perea Monsuwe ve diğerlerinin yaptığı araştırmalara göre, birey alışveriş deneyiminden keyif aldığı takdirde sorunlarından ve hayattan kaçış hissi yaşayarak ayrıca haz da elde edecek ve hedonistik alışveriş gerçekleşmiş olacaktır (Broekhuizen, 2006, s.53-95).Hedonistik tüketim, en genel biçimiyle "tüketicinin ürünle yaşadığı his, hayal ve duygusal tecrübeleri" olarak tanımlanmaktadır ve çoklu duyusal (multisensory), hissel (emotional), bilişsel (cognitive) ve sosyal boyutlardan oluşmaktadır (Hirschman ve Holbrook, 1982,s.92) .

Dittmar (2005) da yaptığı pek çok çalışmada yüksek materyalist değerleri olan kişilerin, özellikle gençlerin, alışveriş bağımlısı olmaya daha duyarlı olduklarını ve bu durumun da artan bir ivmeyle yaşanmaya devam edeceğini savunmaktadır. Benzer şekilde Kasser ve Kanner (2004) ve Roberts ve Martinez (1997) de gençlerde yaşanan daha fazla şey satın almanın artan öneminin yanında, bu edinilenlere yüklenen psikolojik ve sosyal faydanın da alışverişe karşı duygusal değeri bir tehdit olarak alg1lamaktadır.

Hedonik değer, alışverişin ya da bir şeyler satın almanın, bireyi ne kadar eğlendirdiği ve duygusal anlamda neler kattığına ilişkindir ve oldukça özneldir (Tauber,1972, s.47). Hedonizmi benimseyen birey, haz almayı yaşamın amacı olarak görmekte ve tüm kararlarında ihtiyacını giderme ya da hayatta kalma gibi yaşamsal bir hedeften ziyade, keyif arzusundadır (Baudrillard,2010, s.46).

Babin ve diğerleri(1994) yaptıkları çalışmada, bağımlılık eğilimi ve hedonik değerler arasında anlamlı bir ilişki olduğunu saptayarak, haz almak adına alışverişe yönelen bireyin bu terapik etkinin yıkıcı etkisiyle bağımlı haline dönüşebileceğinin altını çizmiştir. Woodruffe-Burton ve diğerleri (2002) de alışverişe holistik açıdan yaptıkları incelemede, alış- 
veriş davranış teorisini geliştirirken, son dönemde ilgi çeken alışveriş bağımlılı̆̆ 1 ve tüketicinin

hedonik değer arayışının etkileşiminin dikkate değer olduğunu ifade etmiştir. Arnold ve Reynolds'in (2003) hedonik tüketimin sadece haz almak için değil farklı nedenlerden de yapılacağını önerdikleri çalışmasında altı diğer sebebe dikkat çekmişlerdir; macera, sosyalleşme, mükâfat, fikir edinmek, hediye ve firsat yakalamak.

Çalışmada literatürle paralel olarak alışveriş bağımlığı ile hedonistik eğilim arasında anlamlı ilişki olduğu varsayılmaktadır.

\section{Duygusal İstikrar}

Birçok araştırmacı psikolog, bireyin karakter ve kişiliğinin en temel düzeyinin değişik boyutlardan meydana geldiğine inanmaktadırlar (Myers ve McCaulley, 1985;Hirsh ve Kummerow, 1990;Atkinson, 1987). Bu kişilik boyutlardan bir tanesi de duygusal istikrardır. Duygusal istikrar, bir kişinin çeşitli koşullar altında duygusal olarak kararlı olduğunu ve anksiyete, depresyon ve / veya diğer yüksek duygusal dalgalanmalara eğilimli olmadığını gösterir (Cheng ve Furnham, 2016). Duygusal istikrar kavramı, duygusal zekayla da ilişkilidir. Kişilerin toplum içerisinde var olabilmeleri, bireylerarası ilişkilerinin, düşünme ve davranış biçimlerinin kilit noktası olarak ifade edilen duygusal zekâ, bireyin kendisinin ve başkalarının hislerini tanıyarak, kendisini motive etmesidir (Yılmaz, 2018, s. 75).

Ayrıca, sosyal yatırım teorisi, duygusal istikrar seviyesinin artması ile iç içe geçmiş kişilik olgunlaşmasının büyük ölçüde normatif yaşamın yetişkin rollerine geçişinin sonucu olduğunu göstermektedir (Bleidorn vd.,2013,s.2338). Yapılan araştırmalarda duygusal istikrarın, utanmaya karşı yüksek kırılganlık, psikolojik esneksizlik ve duygusal düzensizliğe neden olduğu görülmektedir (Paulus vd., 2016,s.380).Jylhä, P., ve Isometsä (2006) ya göre düşük duygusal istikrarlılık düzeyleri strese yatkınlığı artırabilmektedir. Yüksek duygusal istikrar bir dizi psikopatolojik form için bireysel düzeyde bir kaynak olarak tanımlanmıştır (Hwang vd., 2012,s.353). Bleidorn vd. yaptıkları çalışmada duygusal istikrarın geç ergenlik döneminde daha yoğunlaştığını ve yaşa bağlı olarak farklılıklar gösterdiğini ifade etmektedir (Ikeda vd.,2015,s.37).Benzer şekilde, kişilik 
özelliği olarak duygusal istikrarın farklı bağlamsal nedenlerden dolayı değişiklik göstermesi beklenmektedir (Wood ve Denissen, 2015,s.104). Morris vd. (2015) yaptıkları çalışmada duygusal istikrarı dışa dönüklük ve kişilik özellikleri ile ilişkilendirip sonucunda, dışa dönüklük ve duygusal istikrarın, mutluluk ve duruşun pozitif harmanlarının yalnızca bireysel refah ile ilişkili olmadığını, aynı zamanda kişilik faktörleri üzerindeki artan geçerliliğini açıkladığını göstermişlerdir.

Çalışmanın temel amacına bağlı kalmak adına, alışveriş bağımlılığını analiz ederken sıkça kullanılan duyguların bireyi harekete geçirme, duygusal hedeflere ulaşma gibi durumlara etkisi olduğu düşünülen "Duygusal İstikrar" boyutu incelenecektir. Bu doğrultuda, literatür incelendiğinde duygusal anlamda daha dengeli olan bireyde alışveriş bağımlılığına karşı daha az eğilim gözlemlenmesi beklenmektedir.

\section{Finansal Öz-Yetkinlik}

Bandura (1977, 1986, 1997) öz yeterliği, bireyin belirli görevlerde başarılı olabilme becerisine olan inancı olarak tanımlamıştır. Kişinin kendi kendine yeterlilik algısı, bir kişinin zorlukları göze alabilmesinde önemli bir rol oynar. Bandura'ya (1997) göre, bir görevi yerine getirme kabiliyetine güven duyan yüksek düzeyde öz - yeterlilik düzeyine sahip kişilerin, zorluklardan kaçınmak yerine başarılı olmaları daha muhtemeldir.

Finansal öz yetkinlik ise, kişinin finansal tutum ve davranışlarını kendi başına sergileyip finansal kararlar alabilme becerisi olarak tanımlanabilir.

Heath ve Soll(1996), tüketicilerin iradelerini kuvvetlendirmek adına iki mekanizma geliştirdiğini ilkinin bir bütçe belirlemeleri (standart oluşumu) ve ikincisinin de bu bütçe doğrultusunda harcamalarını (gıda, giyim, yeme-içme vs.) belirlediklerini (gözlem süreci) ifade eder. Ancak iradeden bahsedebilmek adına üçüncü bileşen olan "öz-kontrol" gereklidir. Bu da harcamaların bütçeyi aştığı durumlarda dur diyebilme yetisini ifade eder.

Alışveriş bağımlılığının belki de en somut ve yaptırımı olan sonucu, kişiyi sürüklediği finansal zorluktur. Kişinin engelleyemediği bu aşırı satın alım hali, finansal açıdan çoğunlukla borçluluk ve iflasla sonuçlanmaktadır (Edwards,1994, s.86). 
Özyeterlilik, belirli bir görevin başarılabileceği inancı ve kendine güven, motivasyon, iyimserlik ve yaşamın çeşitli zorluklarıyla başa çıabileceği inancı ile ilgilidir (Bandura, 1997,s.2006). Tüketicilerin finansal öz yeterlikleriyle ilgili yetkinliklerini anlayabilmek, eğitimcilere ve danışmanlara yalnızca kendi çıkarları için değil aynı zamanda ekonomi için de faydalı olacak finansal kararlar vermeye yönlendirmede yardımcı olabilmektedir (Lown,2011,s.55).

Finansal memnuniyetten memnuniyetsizlik, genellikle bir aile evinin sinırları içinde ifade edilen özel bir duygu olmuştur (Parrotta ve Johnson, 1998). Ebeveynler arasındaki bu finansal etkileşim ortamı içinde çocuklar,ailelerinin finansal süreçleri nasıl yönettiği hakkında bilgi edinmişlerdir (Hibbert, Beutler ve Martin, 2004). Aslında, Danes (1994) ve Bowen (1995), çok küçük çocuklarla başlayan aile içi yaygın eğitimin daha fazla finansal eğitim için bir temel oluşturduğunu iddia etmiştir.

Finansal öz yetkinlik her ne kadar finansal okuryazarlığı etkileyen faktörler arasında yer alsa da, literatürde bu ilişkinin olmadığını öne süren çalışmalar da bulunmaktadır. Amerika'da üniversite öğrencilerine yönelik olarak Flores (2014) tarafından yapılan tez çalışmasında, finansal öz yetkinlik seviyesinin finansal okuryazarlık düzeyi üzerinde herhangi bir etkisinin olmadığıbelirtilmiştir. Heckman ve Grable (2011), finansal okuryazarlık seviyesi ile finansal öz yetkinlikleri arasındaki ilişkiyi incelemişlerdir. Yazarlar, araştırmaları sonucunda finansal bilgi düzeyi yüksek olan kişilerin finansal öz yetkinliklerinin daha yüksek olduğu sonucuna ulaşmışlardır.

Yapılan çalışmada duygusal istikrar ile hedonik tüketim değişkenlerinin alışveriş bağımlılığ üzerindeki etkisinde finansal öz yetkinlik değişkeninin aracı etkisinin olduğu varsayılmaktadır.

\section{Yöntem}

Bu çalışma verileri Erzincan Üniversitesinde okuyan 598 adet öğrenciye uygulanan anketler neticesinde elde edilmiştir. Araştırmada veri toplama yöntemi olarak yüz yüze anket yöntemi kullanılmıştır. Anket formunun hazırlanmasında literatürdeki çalışmalar ve ölçekler çalışmanın amaçları doğrultusunda revize edilmiştir. Araştırmanın sahip olduğu zaman ve bütçe kısıtları, tesadüfi olmayan örneklem yöntemleri arasın- 
dan, kolayda örneklem yönteminin kullanılmasını uygun kılmaktadır. Kolayda örneklem, kısıtlar nedeniyle, araştırmaya katılacak kişilerin ulaşılabilirliğine göre seçimini esas almaktadır.

Ayrıca, araştırmacılar tarafından sıklıkla kullanılan bu yöntem ile, tesadüfi yöntemlere göre daha iyi sonuçlar almak olasıdır (Yükselen ,2003, s.75). Ankete katılan öğrenciler yakın yaş aralığında olup yaş demografik değişkeni bu sebeple dikkate alınmayarak 5 farklı demografik değişkene göre yapılan çalışma kategorize edilmiştir.Anket çalışması sonucunda katılımcların çoğunluğunun kadın olduğu $(\% 56,2)$ ve aynı zamanda çoğunluk olarak $(\% 59,2)$ aylık geliri 1-500 TL arasında olduğu görülmektedir.

Araştırmada veriler anket tekniği kullanılarak elde edilmiştir. Ankette iki bölüm yer almaktadır. Birinci bölüm katılımcıların demografik özelliklerinin tespitine yönelik sorulardan oluşmaktadır. İkinci bölüm katılımcıların hedonistik eğilim, duygusal istikrar, finansal öz-yetkinlik ve alışveriş bağımlılığı seviyelerini ölçmeye yönelik ölçeklerden oluşmaktadir.

Alışveriş bağımlılığı: Üniversite öğrencilerinin alışveriş bağımlılığını ölçmek için Faber ve O'Guinn(1989) ve Valence vd. (1988) tarafından geliştirilen ölçek kullanılmıştır. "Başkaları, satın alma alışkanlıklarımı bilse dehşete kapılır diye hissediyorum", "Alı̧̧verişe gitmediğim günlerde kendimi sinirli ve endişeli hissederim" gibi 13 ifadeden oluşan bu ölçekte cevaplar 5'li Likert ölçeğine göre (1=Kesinlikle katılmıyorum, 2=Katılmiyorum,

3=Kararsızım, 4=Katılıyorum, 5=Kesinlikle katıliyorum) derecelendirilmiştir.

Hedonistik eğilim: Hausman(2000) tarafından geliştirilen ve türkçe uyarlamasının birçok çalışmada görüldü̆ğü hedonistik eğilim ölçeği kullanılmıştır. "Yarattığı değişiklik hissi için alışveriş yapmaktan hoşlanırım", "Alışveriş yapmak merak duygumu tatmin eder" gibi ifadeleri içeren 6 maddeli ölçek kullanılmıştır. Her bir madde 5'li Likert ölçeğine göre derecelendirilmiştir.

Duygusal İstikrar: Duygusal istikrar ölçeği, Goldberge'in (1992) oluşturduğu ve Saucier"in (1994) revize ettiği ölçek, Mowen ve Spears (1999) tarafından satın alma bağımlılığını daha iyi açıklamak amacıyla kullanılmıştır.Toplam 6 sorudan oluşan duygusal istikrar ölçeğine ait madde- 
ler 5’li Likert ölçeğine göre derecelendirilmiştir. Ölçekte "Başkalarına göre daha aksiyim", "Başkalarına göre daha huysuzum" şeklinde ifadeler yer almaktadır.

Finansal öz-yetkinlik: Finansal öz yetkinliği ölçmek amacıyla kullanılan ölçek Lown (2011) tarafından geliştirilmiş olan "Financial SelfEfficacy Scale"'in Türkçe'ye çevrilip uyarlanması ile oluşturulmuştur. Lown ise ölçeği, Schwarzer ve Jerusalem' in (1995) “General Self-Efficacy Scale" ölçeğinden uyarlamıştır.Toplam 6 sorudan oluşan finansal özyetkinlik ölçeğine ait maddeler 5'li Likert ölçeğine göre derecelendirilmiştir. Ölçekte "Beklenmedik giderler ortaya çıktığından bütçemi yönetmede zorlanırım", "Para biriktirmek benim için zordur"şeklinde ifadeler yer almaktadir.

Araştırma kapsamında güvenilirlikleriyle ilgili cronback Alpha degerleri her bir faktor ve ölcek icin ayri ayri raporlanmistir ve açımlayıcı faktör analizi ve doğrulayıcı faktör analizleri kullanılarak test edilmişlerdir. Daha sonrasında hipotezlerin test edilmesine yönelik olarak oluşturulan model SPSS programı kullanılarak regresyon yöntemi ile test edilmiştir. Bu çalışma kapsamında oluşturulan hipotezlerin test edilmesine yönelik olarak oluşturulan araştırma modeli Şekil 1'de sunulmuştur.

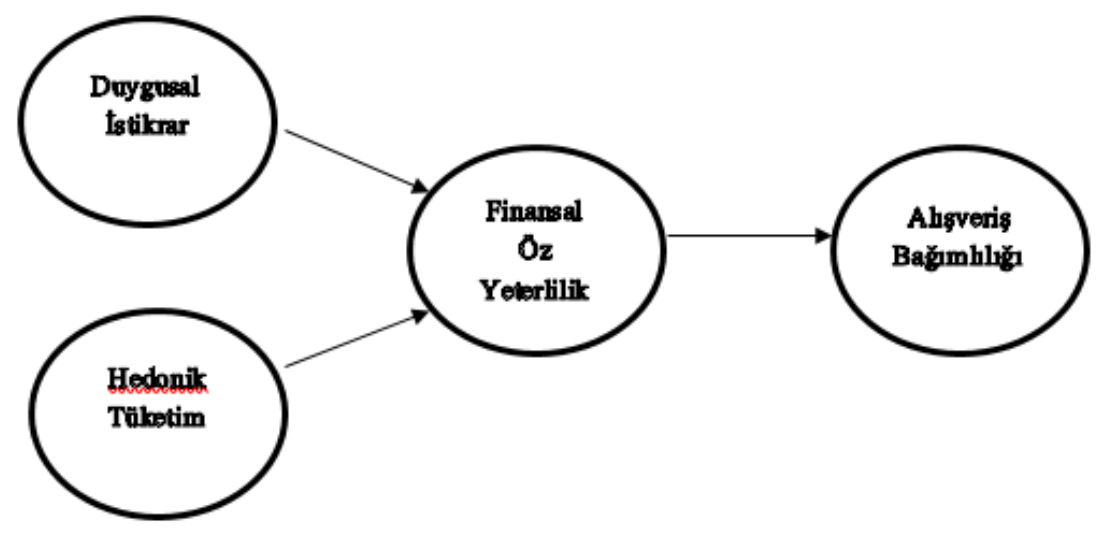

Şekil 1. Model

Oluşturulan model neticesinde; 
- H1: Kategorilere göre'alışveriş bağımlılığı' değişkeninin değerlerinin ortalamaları eşit değildir.

- Ho: Finansal Öz Yetkinlik (Arabulucu), Duygusal İstikrar ve Hedonik Tüketim (Bağımsız Değişkenleri) ile Harcama Eğilimi (Bağımlı Değişken) arasındaki ilişkiyi anlamlı şekilde etkilemez

- H1: Finansal Öz Yetkinlik (Arabulucu), Duygusal İstikrar ve Hedonik Tüketim (Bağımsız Değişken) ile Harcama Eğilimi (Bağımlı Değişken) arasındaki ilişkiye önemli ölçüde aracılık eder

- Ho: Finansal Öz Yetkinlik (Arabulucu), Duygusal İstikrar ve Hedonik Tüketim (Bağımsız Değişkenleri) ile Harcama Sonrası Suçluluk (Bağımlı Değişken) arasındaki ilişkiyi anlamlı şekilde etkilemez.

- H1: Finansal Öz Yetkinlik (Arabulucu), Duygusal İstikrar ve Hedonik Tüketim (Bağımsız Değişken) ile Harcama Sonrası Suçluluk (Bağımlı Değişken) arasındaki ilişkiye önemli ölçüde aracılık eder. hipotezleri sinanacaktır.

\section{Bulgular}

\section{Tanımlayıcı İstatistikler}

Çalışmanın bu bölümünde araştırmaya katılan toplam 598katılımcıdan elde edilen verilerin tanımlayıc istatistiklerine yer verilmiştir. İlk olarak demografik bilgilere ilişkin sorulara verilen cevaplar değerlendirilmiştir.

Sonrasında ise 'duygusal istikrar', 'hedonik tüketim', 'finansal özyetkinlik' ve 'alışveriş bağımlılığı' başlıkları altında yöneltilen sorulara verilen cevaplar ele alınmıştır.Araştırmaya katılan 598katılımcıdan elde edilen verilerin değerlendirilmesi sonucunda, demografik sorulara ilişkin istatistikler Tablo 1.1'de sunulmuştur.

Tablo 1.1 incelendiğinde araştırmaya katılan 598 katılımcının \%56,2'sinin kadın, \%43,8'inin erkek olduğu görülmektedir. Katılımcıların çoğunluğunun $(\% 59,2)$ aylık geliri 1-500 TL arasındadır. Ailedeki toplam aylık geliri 1501-2500 TL ve 2501-5000 TL arasında olan katılımcılar çoğunluktadır (sırasıyla \%36,5 ve \%35,1). Öğrenim düzeylerine bakıldığında ise hem annenin hem de babanın öğrenim düzeylerinin çoğunlukla ilkokul ve altı olduğu görülmektedir (sırasıyla $\% 57,5$ ve $\% 31,1$ ). 
Tablo 1. Demografik Sorulara İlişkin İstatistikler

\begin{tabular}{llll}
\hline & & Frequency & Percent (\%) \\
\hline \multirow{2}{*}{ Cinsiyet: } & Kadın & 336 & 56,2 \\
& Erkek & 262 & 43,8 \\
\hline \multirow{3}{*}{ Aylık gelir: } & $1-500 \mathrm{TL}$ & 354 & 59,2 \\
& $501-1500 \mathrm{TL}$ & 196 & 32,8 \\
& $1501-2500 \mathrm{TL}$ & 24 & 4,0 \\
& $2501 \mathrm{TL}$ ve üzeri & 24 & 4,0 \\
\hline \multirow{3}{*}{ Ailedeki toplam aylık } & $1-1500 \mathrm{TL}$ & 78 & 13,0 \\
gelir: & $1501-2500 \mathrm{TL}$ & 218 & 36,5 \\
& $2501-5000 \mathrm{TL}$ & 210 & 35,1 \\
& $5001 \mathrm{TL}$ ve üzeri & 92 & 15,4 \\
\hline \multirow{3}{*}{ Annenin öğrenim düzeyi: } & İlkokul ve altı & 344 & 57,5 \\
& Ortaokul & 128 & 21,4 \\
& Lise & 110 & 18,4 \\
& Üniversite ve üstü & 16 & 2,7 \\
\hline \multirow{3}{*}{ Babanın öğrenim düzeyi: } & İkokul ve altı & 186 & 31,1 \\
& Ortaokul & 174 & 29,1 \\
& Lise & 156 & 26,1 \\
& Üniversite ve üstü & 82 & 13,7 \\
\hline & Değişken & \multirow{2}{*}{598} & 100,0 \\
\hline
\end{tabular}

Anket formunda, ölçeklere ilişkin toplamda 31 soru bulunmaktadır. Bu sorulara verilen yanitlar 'Kesinlikle katılmiyorum', 'Katılmıyorum', 'Kararsızım', 'Katılıyorum' ve 'Kesinlikle katılıyorum' şeklinde olup, araştırmaya katılan toplam 598 katılımcının söz konusu sorulara verdikleri yantların ortalaması incelendiğinde, katılımcların 16ifadeyekatılmadıkları (kesinlikle katılmıyorum/katılmıyorum şeklinde cevap verdikleri) ve 15 ifadeye karşı ise kararsızlık sınırında oldukları (kararsızım şeklinde cevap verdikleri) söylenebilir. Katılımcıların katıldıkları (katılıyorum/kesinlikle katılıyorum şeklinde cevap verdikleri) ifadenin ise olmadığ görülmektedir. (Ortalama puanın 0,00-2,50olduğu aralık katılımcıların ifadeye katılmadıklarını, 2,50-3,50 aralığı kararsız olduklarını, 3,50-5,00 aralığı ise katıldıklarını göstermektedir).

Ortalamalara göre katılımcıların katılmadıkları ifadeler 'Başkalarına göre daha huysuzum. (Ort.=2,27)', 'Diğer insanları izlemek için alışveriş yapmaya giderim. (Ort.=1,64)', 'Beklenmedik giderler ortaya çıktığında, kredi veya borç almak zorunda kalırım. (Ort. $=2,41)^{\prime}$, 'Finansal bir zorlukla karşılaştığımda, çözüm bulmakta zorlanırım.(Ort.=2,23)', 'Bütçemi 
yönetmek konusunda kendime güvenim azdır.(Ort.=2,00)', 'Başkaları, satın alma alışkanlıklarımı bilse dehşete kapılır diye hissediyorum. (Ort.=1,71)', 'Alışverişe gitmediğim günlerde kendimi sinirli ve endişeli hissederim. (Ort.=1,59)', 'Alışveriş yapıp eve gittiğimde bazı ürünleri neden satın aldığıma emin olamam. (Ort. $=2,42$ )', 'Ne aldığımı umursamadan yalnızca bir şeyler satın almak istediğim olur. (Ort.=1,95)', 'Alı̧̧veriş sonrasında strese girerim. (Ort. $=2,05)$ ', 'Birçok alışverişimde kendimden geçerim ve bunu durdurmam mümkün olmaz. (Ort. $=1,91)^{\prime}$, 'Alışveriş yapmak sürekli aklımdadır. (Ort.=2,18)', 'Eğer param varsa, birazını ya da hepsini mutlaka harcamalıyım. (Ort.=2,43)', 'Çoğu zaman mağazada gördüğü bir şeyi planlamadan, sadece benim olmasını istediğim için alırım. (Ort.=2,17)', 'Çoğu zaman alışveriş yapmak için dayanılmaz bir istek duyuyorum. (Ort. $=2,34$ )', 'Paramın az kaldığını bilmeme rağmen, ihtiyacım olmayan ürünler aldığım olmuştur. (Ort.=2,43)' isimli ifadelerdir.

Ortalamalara göre katılımcıların kararsızlık sınırında oldukları ifadeler ise 'Başkalarına göre daha aksiyim. (Ort.=2,60)', 'Başkalarına göre daha alınganım. (Ort.=2,68)', 'Başkalarına göre daha değişken duygularım var. (Ort.=3,20)', 'Başkalarına göre daha asabiyim. (Ort.=2,71)', 'Başkalarına göre daha kıskancım. (Ort.=2,79)', 'Yarattı̆̆ değişiklik hissi için alışveriş

yapmaktan hoşlanırım. (Ort.=2,98)', 'Alışveriş yapmak merak duygumu tatmin eder. (Ort.=2,57)', 'Alı̧̧veriş yapmak bana yeni deneyimler sunar. $(\mathrm{Ort} .=2,74)^{\prime}$ ', 'Alışveriş yaparken yenidünyalar keşfediyormuşum gibi hissederim. (Ort. $=2,54$ )', 'Eğlenmek için alışveriş yapmaya giderim. $(\text { Ort. }=2,69)^{\prime}$, ‘Beklenmedik giderler ortaya çıktığından bütçemi yönetmede zorlanırım. (Ort.=2,57)', 'Para biriktirmek benim için zordur. (Ort. $=2,65)^{\prime}$, 'Paramın zamanından önce bitmesinden endişe duyarım. $(\text { Ort. }=2,94)^{\prime}$, 'Bazen içimde bir şeylerin beni alı̧̧veriş yapmaya ittiğini hissediyorum. (Ort.=2,53)' ve 'Para harcamayı seviyorum. (Ort.=2,97)' isimli ifadelerdir. 
Cinsiyet ve Gelir Demografik Değişkenlerinin Alışveriş Bağımlılı̆̆ı Üzerindeki Etkisi

Burada 'alışveriş bağımlılığı' değişkeni ile cinsiyet ve gelir durumu arasındaki ilişkileri ortaya çıkarmak amacıyla, ikili ve çoklu karşılaştırmalar için kullanılan bağımsız gruplar t-testi ve varyans analizine başvurulmuştur. 'Cinsiyet' değişkeni iki kategoriye sahiptir. Bağımlı değişken olan 'alışveriş bağımlılı̆̆g' değişkeninin değerlerinin, cinsiyet değişkeninin kategorilerine göre farklılaşıp farklılaşmadığı bağımsız gruplar t-testi ile test edilmiştir. Bunun için elde edilen çıktılar yorumlanırken öncelikle, her bir değişken için;

- Ho: Kategorilere göre'alışveriş bağımlılı̆̆ı' değişkeninin değerlerinin varyansları eşittir.

- H1: Kategorilere göre'alışveriş bağımlılığı' değiş̧keninin değerlerinin varyansları eşit değildir.

Hipotezi test edilecek, sonuca göre ise,

- Ho: Kategorilere göre'alışveriş bağımlılı̆̆g' değişkeninin değerlerinin ortalamaları eşittir.

- H1: Kategorilere göre'alışveriş bağımlılı̆̆ı' değişkeninin değerlerinin ortalamaları eşit değildir.

hipotezleri sınanacaktır.Yapılan bağımsız gruplar t-testine göre elde edilen analizler neticesinde cinsiyet değişenine ilişkin sonuçlar incelendiğinde, Levene testinin yer aldığ ilk sütun kontrol edildiğinde F istatistiğinin 0,319 ve $p$ değerinin ise 0,572 olduğu görülmektedir. $P$ değeri 0,05 'ten büyük olduğundan varyansların eşitliğine dair olan $\mathrm{H}_{0}$ hipotezi reddedilemeyerek varyansların eşit olduğu sonucuna varılır. Bu durumda ortalamaların eşitliğine dair sıfır hipotezini test etmek için cinsiyet değişkenine aitilk satır kontrol edilir. İlk satıra ilişkin p değeri 0,001 olup, 0,05'ten küçük olduğundan Horeddedilecektir. Bu durumda 'alışveriş bağımlılığı' değişkeninin ortalamalarının cinsiyet değişkenin kategorilerine göre farklılaştı̆̆ı söylenir. 
Tablo 2. Grup istatistikleri

\begin{tabular}{llllll}
\hline Kategoriler & & N & Mean & Std. Deviation & Std. Error Mean \\
\hline \multirow{2}{*}{ Cinsiyet } & Kadın & 336 & 2,3186 & 0,84781 & 0,04625 \\
& Erkek & 262 & 2,0737 & 0,88215 & 0,05450 \\
\hline
\end{tabular}

Hangi kategori lehine bir farklılık olduğunun tespit edilmesi için Tablo 2'de yer alan ortalama sütununa bakıldığında, kadın katılımcıların erkek katılımcılara göre alışveriş bağımlılıklarının daha fazla olduğu görülmektedir $\left(\mu_{\text {kadın }}=2,3186 ; \mu_{\text {erkek }}=2,0737\right)$.

'Gelir durumu' isimli değişken ikiden fazla kategoriye sahiptir. Bu değişkenin kategorilerine göre 'alışveriş bağımlılı̆̆ı' değişkeninin değerlerinin farklılaşıp farklılaşmadığı tek yönlü varyans analizi ile test edilmiştir. Tek yönlü varyans analizinin yapılabilmesi için grupların varyanslarının eşit olması gerekmektedir. Bunun için varyans analizine geçmeden önce varyansların eşitliğinin test edilmesi amacıyla;

- Ho: Kategorilere göre'alışveriş bağımlılı̆̆1' değişkeninin değerlerininvaryansları eşittir.

- H1: Kategorilere göre'alışveriş bağımlılığı' değişkeninin değerlerininvaryansları eşit değildir.

hipotezinin test edilmesi gerekmektedir. Bunun için varyansların eşitliğinin test edilmesinde kullanılan Levene's testi sonuçlarına Tablo 3'te yer verilmiştir. Analiz sonuçları incelendiğinde, tek yönlü varyans analizini yapmada gerekli ön şartın sağlandığı görülmektedir(p değeri $=0,165>0,05)$. Bu durumda,'alışveriş bağımlılı̆̆g' değişkeninin değerlerinin kategorilere göre farklılık gösterip göstermediğini test etmede tek yönlü varyans analizi kullanılacaktır.

Tablo 3. Varyanslarm homojenliğinin testi

\begin{tabular}{lllll}
\hline & Levene İstatistiği & df1 & df2 & Sig. \\
\hline Gelir durumu & 1,706 & 3 & 594 & 0,165 \\
\hline
\end{tabular}

Varyans analizinde test edilecek hipotezler aşağıdaki gibidir:

- Ho: Kategorilere göre 'alışveriş bağımlılığı' değişkeninin değerlerinin ortalamaları farklılık göstermez.

- H1: Kategorilere göre 'alışveriş bağımlılığı' değişkeninin değerlerinin ortalamaları farklılık gösterir. 
Gerçekleştirilen varyans analizi sonucunda elde edilen ANOVA tablosu Tablo 4'te sunulmaktadır. Tablo 4 incelendiğinde 'gelir durumu' değişkeni için yapılan tek yönlü varyans analizi sonucunda elde edilen $F$ değeri3,765 ve buna karşılık gelen p değeri 0,011 olarak bulunmuştur. Bu durumda $\mathrm{p}$ değeri 0,05 'ten küçük olduğu için $\mathrm{H}_{0}$ hipotezi reddedilecek ve 'alışveriş bağımlılığı' değişkeninin değerlerinin 'gelir durumu' değişkeninin kategorilerine göre farklılık gösterdiği sonucuna ulaşılacaktır.

Tablo 4. ANOVA

\begin{tabular}{llllll}
\hline & Sum of Squares & df & Mean Square & F & Sig. \\
\hline $\begin{array}{l}\text { Between } \\
\text { Groups }\end{array}$ & 8,448 & 3 & 2,816 & 3,765 & 0,011 \\
\hline $\begin{array}{l}\text { Within } \\
\text { Groups }\end{array}$ & 444,277 & 594 & 0,748 & & \\
\hline Total & 452,725 & 597 & & & \\
\hline
\end{tabular}

Farklılığın hangi kategorilerden kaynaklandığının tespit edilmesi için LSD testi yapılmış ve sonuçlar incelendiğinde;501-1500Tl ile 1-500Tl kategorileri arasinda (meandifference $=0,20101$ ) ve 1501-2500Tl ile 1$500 \mathrm{Tl}$ kategorileri arasinda (meandifference $=0,45087$ ) anlamlı bir farklılık olduğu görülmüştür. Bu üç kategori baz alındığında gelir durumu arttıkça katılımcıların alışveriş bağımlılıklarının da arttı̆̆ını söylemek mümkündür.

\section{Güvenilirlik ve Faktör Analizi Sonuçları}

Çalışmada kullanılan anket formunda toplam 31 soru yer almaktadır. Bu soruların tamamı için elde edilen Cronbach's alpha katsayısı 0,758 olarak bulunmuştur. Bu değer söz konusu anketin yüksek güvenilirlik düzeyine sahip olduğunu göstermektedir.

Ankette yer alan 31 soru için 598 katılımcıdan elde edilen verilere faktör analizi uygulanmıştır. Faktör analizi "duygusal istikrar', 'hedonik tüketim', 'finansal öz-yetkinlik' ve 'alışveriş bağımlılığı' ölçekleri için ayrı ayrı gerçekleştirilmiştir. Öncelikle soruların faktör analizine uygunluğunun test edilmesi için Kaiser-Meyer-Olkin (KMO) örnekleme yeterliliği ve Bartlett küresellik testi yapılmıştır. Bu test doğrultusunda, her bir ölçek için KMO değerinin 0,50'nin üzerinde olması ve Bartlett küresellik 
testinin 0,05 önem seviyesinde anlamlı olması sonucu veri setinin faktör analizine uygun olduğuna karar verilmiştir.

Tablo 5. KMO ve Bartlett Küresellik Testi Sonuçları

\begin{tabular}{lllrl}
\hline & & \multicolumn{3}{c}{ Bartlett testi } \\
\cline { 3 - 5 } Ölçek & KMO & Ki-kare & df & Sig. \\
\hline Duygusal istikrar & 0,787 & 1285,206 & 15 & 0,000 \\
Hedonik tüketim & 0,849 & 1777,691 & 15 & 0,000 \\
Finansal öz yetkinlik & 0,852 & 1023,765 & 15 & 0,000 \\
Alışveriş bağımlılığ1 & 0,901 & 3599,673 & 78 & 0,000 \\
\hline
\end{tabular}

Soruların faktör analizine uygunluğuna karar verildikten sonra faktör analizine geçilmiştir. Bu analiz kapsamında sosyal bilimlerde en yaygın kullanılan faktör türetme tekniklerinden temel bileşen faktörü ve yine en sık kullanılan dik döndürme tekniklerinden varimax döndürme tekniği kullanılmıştır.

'Duygusal istikrar' ölçeği için gerçekleştirilen faktör analizi sonucunda verilerin tek faktörle açılanabilir olduğuna karar verilmiştir. Faktör ağırlıkları Tablo 3.'de sunulmuştur. Her bir sorunun aynı fikri ölçüp ölçmediği ve böylece ölçekteki maddelerin içsel tutarlılığının olup olmadığının araştırıldığı güvenilirlik analizinde dikkate alınan Cronbach's Alpha içsel güvenilirlik indeksi söz konusu faktör için de 0,804olarak hesaplanmıştır.

Tablo 6. 'Duygusal İstikrar' Ölçeğine Uygulanan Faktör ve Güvenilirlik Analizi Sonuçları

\begin{tabular}{lll}
\hline Kod & Soru İfadesi & Faktör Ağırlıkları \\
\hline & Faktörün Adı: Duygusal İstikrar & \\
S1 & Başkalarına göre daha aksiyim. & 0,837 \\
S2 & Başkalarına göre daha huysuzum. & 0,812 \\
S5 & Başkalarına göre daha asabiyim. & 0,784 \\
S4 & Başkalarına göre daha değisken duygularım var. & 0,664 \\
S3 & Baškalarına göre daha alınganım. & 0,625 \\
S6 & Başkalarına göre daha kıskancı. & 0,547 \\
\hline
\end{tabular}

Faktörün açıklayıchlı̆̆l: \%51,765 ve faktörün güvenilirlĭği: 0,804

'Hedonik tüketim' ölçeği için gerçekleştirilen faktör analizi sonucunda yine verilerin tek faktörle açıklanabilir olduğuna karar verilmiştir.Faktör analizi sonucuna göre faktör ağırlığı 0,40 'ın altındaolan $(0,303)$ 'Diğer 
insanları izlemek için alışveriş yapmaya giderim.' isimli ifade analiz dışı bırakılmış, kalan ifadeler üzerinden yeniden faktör analizi uygulanmıştır. Nihai analize göre, $\mathrm{KMO}=0,866, \chi 2$ Bartlett test $(10)=1711,565$, $\mathrm{p}=0,000$ olarak bulunmuştur. Analiz sonuçları Tablo 2.3'te sunulmuştur. Bu ölçek için Cronbach's Alpha içsel güvenilirlik indeksi ise 0,890olarak hesaplanmıştır.

Tablo 7. 'Hedonik Tüketim' Ölçeğine Uygulanan Faktör ve Güvenilirlik Analizi Sonuçları

\begin{tabular}{lll}
\hline Kod & Soru İfadesi & $\begin{array}{l}\text { Faktör } \\
\text { Ağırlıkları }\end{array}$ \\
\hline & Faktörün Adı: Hedonik Tüketim & \\
S8 & Alışveriş yapmak merak duygumu tatmin eder. & 0,894 \\
S9 & Alışeriş yapmak bana yeni deneyimler sunar. & 0,866 \\
S10 & Alışveriş yaparken yeni dünyalar keşfediyormuşum gibi hissederim. & 0,844 \\
S7 & Yarattığ1 değişiklik hissi için alışveriş yapmaktan hoşlanırım. & 0,817 \\
S12 & Eğlenmek için alışveriş yapmaya giderim. & 0,753 \\
\hline Faktörün açıklayıcılığı: \%69,909 ve faktörün güvenilirliği: 0,890 & \\
\hline
\end{tabular}

'Finansal öz-yetkinlik' ölçeği için gerçekleştirilen faktör analizi sonucunda verilerin tek faktörle açıklanabilir olduğuna karar verilmiştir (Tablo 5). Söz konusu ölçek için Cronbach's Alpha değeri 0,810olarak hesaplanmıştır.

Tablo 8. 'Finansal Öz-Yetkinlik' Ölçeğine Uygulanan Faktör ve Güvenilirlik Analizi Sonuçları

\begin{tabular}{|c|c|c|}
\hline Kod & Soru İfadesi & $\begin{array}{l}\text { Faktör } \\
\text { Ağırlıkları }\end{array}$ \\
\hline & Faktörün Adı: Finansal Öz Yetkinlik & \\
\hline S29 & Finansal bir zorlukla karşılaştı̆̆ımda, çözüm bulmakta zorlanırım. & 0,771 \\
\hline S27 & Para biriktirmek benim için zordur. & 0,753 \\
\hline S26 & $\begin{array}{l}\text { Beklenmedik giderler ortaya çıktığından bütçemi yönetmede zorla- } \\
\text { nırım. }\end{array}$ & 0,743 \\
\hline S28 & $\begin{array}{l}\text { Beklenmedik giderler ortaya çıktığında, kredi veya borç almak zo- } \\
\text { runda kalırım. }\end{array}$ & 0,727 \\
\hline S30 & Bütçemi yönetmek konusunda kendime güvenim azdır. & 0,720 \\
\hline S31 & Paramın zamanından önce bitmesinden endişe duyarım. & 0,599 \\
\hline
\end{tabular}

Faktörün açıklayıcllığı: \%51,993 ve faktörün güvenilirliği: 0,810

'Alışveriş bağımlılığı' ölçeği için gerçekleştirilen faktör analizi sonucunda verilerin iki faktörle açıklanabilir olduğuna karar verilmiştir. Fak- 
tör analizi sonucuna göre her iki faktör altında da yüksek ağırlığa sahip olan'Birçok alışverişimde kendimden geçerim ve bunu durdurmam mümkün olmaz.' ve 'Çoğu zaman mağazada gördügüum bir şeyi planlamadan, sadece benim olmasını istediğim için alırım.' isimli ifadeler analiz dışı bırakılmış, kalan ifadeler üzerinden yeniden faktör analizi uygulanmıştır. Nihai analize göre, $\mathrm{KMO}=0,878, \chi 2$ Bartlett test (55) $=2742,817$, $\mathrm{p}=0,000$ olarak bulunmuştur. Analiz sonucunda elde edilen iki faktör tarafından açıklanan toplam varyans \%56,468 olarak hesaplanmıştır. Sonuçlar Tablo 9'da sunulmuştur. Cronbach's Alpha içsel güvenilirlik indeksi birinci faktör için 0,836 olarak, ikinci faktör için ise 0,777 olarak hesaplanmıştır. Literatür incelendiğinde

Tablo 9. 'Alışveriş Bağımlılı̆̆ı' Ölçeğine Uygulanan Faktör ve Güvenilirlik Analizi Sonuçları

\begin{tabular}{|c|c|c|}
\hline Kod & Soru İfadesi & $\begin{array}{l}\text { Faktör } \\
\text { Ağırlıklar }\end{array}$ \\
\hline & Faktörün Adı: Faktör 1(Harcama eğilimi) & \\
\hline S24 & Para harcamayı seviyorum. & 0,758 \\
\hline S22 & $\begin{array}{l}\text { Bazen içimde bir şeylerin beni alışveriş yapmaya ittiğini } \\
\text { hissediyorum. }\end{array}$ & 0,748 \\
\hline S23 & $\begin{array}{l}\text { Çoğu zaman alışveriş yapmak için dayanılmaz bir istek } \mathrm{d} \\
\text { uyuyorum. }\end{array}$ & 0,734 \\
\hline S19 & Alışveriş yapmak sürekli aklımdadır. & 0,697 \\
\hline S20 & $\begin{array}{l}\text { Eğer param varsa, birazını ya da hepsini mutlaka } \\
\text { harcamalıyım. }\end{array}$ & 0,684 \\
\hline S25 & $\begin{array}{l}\text { Paramın az kaldığını bilmeme rağmen, ihtiyacım olmayan ürünler } \\
\text { aldığım olmuştur. }\end{array}$ & 0,542 \\
\hline \multicolumn{3}{|c|}{ Faktörün açılayıcıllŭg: \%32,212 ve faktörün güvenilirliği: 0,836} \\
\hline & Faktörün Adı: Faktör 2 (Harcama sonrası suçluluk) & \\
\hline S17 & Alı̧veriş sonrasında strese girerim. & 0,786 \\
\hline S15 & $\begin{array}{l}\text { Alşveriş yapıp eve gittiğimde bazı ürünleri neden satın } \\
\text { aldığıma emin olamam. }\end{array}$ & 0,697 \\
\hline S14 & Alışverişe gitmediğim günlerde kendimi sinirli ve endişeli hissederim. & 0,680 \\
\hline S13 & $\begin{array}{l}\text { Başkaları, satın alma alışkanlıklarımı bilse dehşete kapılır diye hissedi- } \\
\text { yorum. }\end{array}$ & 0,592 \\
\hline S16 & $\begin{array}{l}\text { Ne aldığımı umursamadan yalnızca bir şeyler satın almak istediğim } \\
\text { olur. }\end{array}$ & 0,556 \\
\hline
\end{tabular}

O"Guinn ve Faber"e in önerdiği dört aşamalı alışveriş bağımlılığı aşamalarını, harcama eğilimi ile başlayan ve harcama sonrası suçluluk ile 
sonlanan, Edwards „1n (1993) iki faktöre sahip ölçek şeklinde revize edilmiş ve farklı çalışmalarda kullanılmıştır. Yapılmış olan çalışmada da uygulanan faktör analizi sonrasında literatüre paralel olarak verilerin iki faktör ışığında analiz edilmesi uygun bulunmuştur.

\section{Model Sonuçları}

Çalışmanın bu bölümünde araştırmaya konu olan temel hipotez test edilecektir. Her bir ölçekten elde edilen faktörlerin ortalama puanları alınmış, bu ortalama puanlar kullanılarak analizler gerçekleştirilmiştir. Ölçeklerden elde edilen faktörler için hesaplanan ortalama puanlara ait tanımlayıc istatistikler Tablo 10 'da sunulmaktadır.

Tablo 10. Ölçekler ve Bu Ölçeklerden Elde Edilen Faktörler İçin Hesaplanan Ortalama Puanlara Ait Tanımlayıci İstatistikler

\begin{tabular}{lcccccc}
\hline & Ortalama & Medyan & Mod & $\begin{array}{l}\text { Std. } \\
\text { Sapma }\end{array}$ & Çarpıklık & Basıklık \\
\hline $\begin{array}{l}\text { Duygusal } \\
\text { Istikrar }\end{array}$ & 3,2921 & 3,3333 & 3,00 & 0,94319 & $-0,314$ & $-0,238$ \\
\hline $\begin{array}{l}\text { Hedonik } \\
\text { Tüketim }\end{array}$ & 2,7050 & 2,6000 & 1,00 & 1,19151 & 0,234 & $-0,922$ \\
\hline $\begin{array}{l}\text { Finansal Öz } \\
\text { Yetkinlik }\end{array}$ & 3,5334 & 3,6667 & 5,00 & 0,97254 & $-0,470$ & $-0,343$ \\
\hline $\begin{array}{l}\text { Alışveriş } \\
\text { Bağımlılı̆̆ }\end{array}$ & & & & & & \\
\hline $\begin{array}{l}\text { Faktör 1 } \\
\text { Faktör 2 }\end{array}$ & 2,4794 & 2,3333 & 1,67 & 1,04453 & 0,590 & $-0,450$ \\
\hline
\end{tabular}

Çalışmada ele alınan model Şekil 1'deki gibidir, lakin yapılan faktör analizleri neticesinde Alışveriş bağımlılığı ölçeği iki faktörle temsil edildiği için yeni model Şekil 2'de gösterildiği üzere iki faktör için ayrı ayrı test edilecektir. Model, 'duygusal istikrar' ve 'hedonik tüketim' değişkenlerinin 'alışveriş bağımlılığı' üzerinde etkisi olduğu ve bu etkiye 'finansal öz yetkinlik' isimli değişkenin aracılık ettiği şeklinde ifade edilebilir. Modelde aracılık etkisinden söz edebilmek için bazı koşulların sağlanması gerekir. Öncelikle bağımsız değişkenin aracı değişken üzerinde ve bağımsız değişkenin bağımlı değişken üzerinde anlamlı bir etkisi olmalıdır. Aracı değişken, ikinci adımdaki regresyon analizine dâhil edildiğinde; bağımsız değişkenle bağımlı değişken arasında anlamlı olma- 
yan ilişki ortaya çıkarsa tam aracılık etkisinden; bağımsız değişken ile bağımlı değişken arasındaki ilişkide azalma meydana gelirse kısmi aracılık etkisinden söz edilecektir.

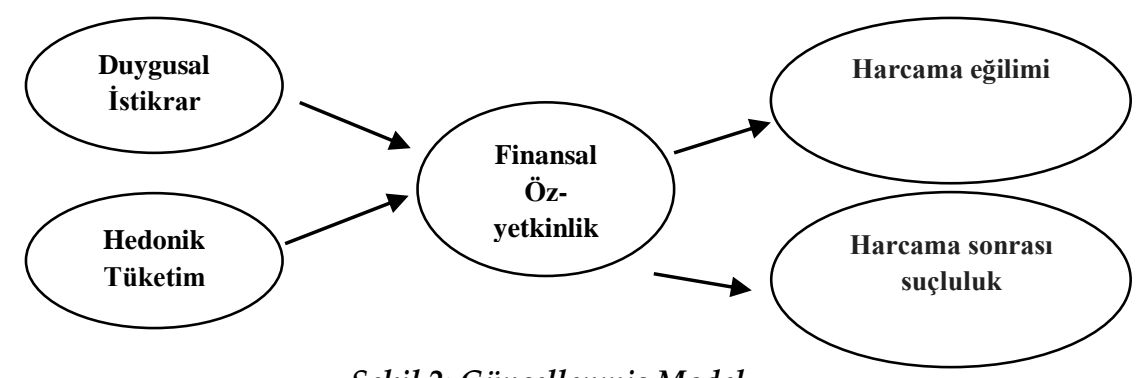

Şekil 2: Güncellenmiş Model

Burada 'duygusal istikrar' ve 'hedonik tüketim' değişkenleri bağımsız değişken, 'alışveriş bağımlılığı' değişkeni bağımlı değişken, 'finansal öz yetkinlik' değişkeni ise aracı değişken rolündedir. 'Alışveriş bağımlılı̆̆ı' değişkeni 'Harcama eğilimi' ve 'Harcama sonrası suçluluk' olmak üzere iki faktör ile temsil edilmektedir. Dolayısıyla bu iki değişkenin tek tek bağımlı değişken rolünde olduğu iki ayrı model tahmin edilmiştir. Model-1'de 'Faktör 1' değişkeni, Model-2'de ise 'Faktör 2' değişkeni bağıml değişken olarak ele alınmıştır. Model sonuçları Tablo 11a ve 11b'de sunulmaktadır.

Model 1 sonuçlarına bakıldığında bağımsız değişkenlerin (duygusal istikrar ve hedonik tüketim) aracı değişken (finansal öz yetkinlik) üzerindeki etkisinin (sırasıyla $\beta=0,244$ ve $\beta=-0,113$ ) ve bağımsız değişkenlerin(duygusal istikrar ve hedonik tüketim) bağımlı değişken (harcama eğilimi) üzerindeki etkisinin (sırasıyla $\beta=-0,145$ ve $\beta=0,516$ ) anlamlı oldu$\breve{g} u$ görülmektedir. Duygusal istikrar, hedonik tüketim ve finansal öz yetkinlik değişkenleri faktör 1değişkenini kestirmek için birlikte modele dâhil edildiğinde, hedonik tüketim değişkeninin faktör 1 değişkeni üzerindeki etkisinin azaldığ $(\beta=0,475)$ ve bu etkinin anlamlı olduğu görülmektedir. Buna göre finansal öz yetkinlik değişkeninin, hedonik tüketim ile harcama eğilimi arasında kısmi aracı rolüne sahip olduğu söylenebilmektedir. Son adımda duygusal istikrar değişkeninin katsayısı anlam1 olmadığı için, finansal öz yetkinlik değişkeninin duygusal istikrar ile harcama eğilimi arasındaki aracılık etkisinden bahsedilemeyecektir. 
Harcama sonrası suçluluk ile Duygusal istikrar ve Hedonik tüketim arasında pozitif bir ilişki olduğu, ayrıca Hedonik tüketimin Finansal öz yetkinlik üzerindeki negatif etkisinden dolayı, Finansal öz yetkinliğin Harcama sonrası suçluluk üzerinde negatif bir mediator etkisi olduğu gözlemlenmiştir.

Tablo 11a. Model 1 Sonuçları

\begin{tabular}{|c|c|c|c|c|c|c|}
\hline & & $\beta$ & $\mathbf{t}$ & Sig. & Tolerance & VIF \\
\hline \multicolumn{7}{|c|}{$\begin{array}{l}\text { 1. Adım } \\
\text { Bağımlı değişken: } \\
\text { 'finansal öz-yetkinlik' }\end{array}$} \\
\hline \multirow[t]{2}{*}{$\begin{array}{l}\text { Bağımsız } \\
\text { değişken: }\end{array}$} & $\begin{array}{l}\text { 'duygusal } \\
\text { istikrar' }\end{array}$ & 0,244 & 6,102 & 0,000 & \multirow{3}{*}{0,960} & \multirow{2}{*}{1,042} \\
\hline & $\begin{array}{l}\text { 'hedonik } \\
\text { tüketim' }\end{array}$ & $-0,113$ & $-2,287$ & 0,005 & & \\
\hline \multicolumn{6}{|c|}{$\mathrm{F}=27,176$; Sig. $=0,000$; R kare $=0,084$; Düzeltilmiş $\mathrm{R}$ kare $=0,081$} & \\
\hline \multicolumn{7}{|c|}{$\begin{array}{l}\text { 2. Adım } \\
\text { Bağımlı değişken: } \\
\text { ‘Harcama eğilimi' }\end{array}$} \\
\hline \multirow[t]{2}{*}{$\begin{array}{l}\text { Bağımsız } \\
\text { değişken: }\end{array}$} & $\begin{array}{l}\text { ‘duygusal } \\
\text { istikrar' }\end{array}$ & $-0,145$ & $-4,187$ & 0,000 & \multirow{2}{*}{0,960} & \multirow{2}{*}{1,042} \\
\hline & $\begin{array}{l}\text { 'hedonik } \\
\text { tüketim' }\end{array}$ & 0,516 & 14,931 & 0,000 & & \\
\hline \multicolumn{7}{|c|}{$\mathrm{F}=138,371$; Sig. $=0,000 ; \mathrm{R}$ kare $=0,317$; Düzeltilmiş $\mathrm{R}$ kare $=0,315$} \\
\hline \multicolumn{7}{|c|}{$\begin{array}{l}\text { 3. Adım } \\
\text { Bağımlı değişken: } \\
\text { ‘Harcama eğilimi' }\end{array}$} \\
\hline \multirow[t]{3}{*}{$\begin{array}{l}\text { Bağımsız } \\
\text { değişken: }\end{array}$} & $\begin{array}{l}\text { ‘duygusal } \\
\text { istikrar' }\end{array}$ & $-0,055$ & $-1,717$ & 0,086 & 0,903 & 1,107 \\
\hline & $\begin{array}{l}\text { 'hedonik } \\
\text { tüketim' }\end{array}$ & 0,475 & 15,045 & 0,000 & 0,947 & 1,056 \\
\hline & $\begin{array}{l}\text { 'finansal } \\
\text { yetkinlik' }\end{array}$ & $-0,365$ & $-11,380$ & 0,000 & 0,916 & 1,091 \\
\hline \multicolumn{7}{|c|}{$\mathrm{F}=155,344$; Sig. $=0,000$; $\mathrm{R}$ kare $=0,440$; Düzeltilmiş $\mathrm{R}$ kare $=0,437$} \\
\hline
\end{tabular}

Model 2 sonuçlarına bakıldığında yine bağımsız değişkenlerin (duygusal istikrar ve hedonik tüketim) aracı değişken (finansal öz yetkinlik) üzerindeki etkisinin (sırasıyla $\beta=0,244$ ve $\beta=-0,113$ ) anlamlı olduğu görülmektedir. Zira bağımsız değişkenler ve aracı değişken bir önceki model ile aynıdır. Ayrıca model 2'de bağımsız değişkenlerin (duygusal istikrar ve hedonik tüketim) bağımlı değişken (harcama sonrası suçluluk) üzerindeki etkisinin de (sırasıyla $\beta=-0,177$ ve $\beta=0,434$ ) anlamlı olduğu 
görülmektedir. Son adımda duygusal istikrar, hedonik tüketim ve finansal öz yetkinlik değişkenleri harcama sonrası suçlulukdeğişkenini kestirmek için birlikte modele dâhil edilmiştir.Bu adımda hem duygusal istikrar hem de hedonik tüketim değişkeninin harcama sonrası suçluluk değişkeni üzerindeki etkisinin mutlak değerce azaldığı (sırasıyla $\beta=-$ 0,088 ve $\beta=0,392$ ) ve bu etkilerin anlamlı olduğu görülmektedir. Buna göre finansal öz-yetkinlik değişkeninin, duygusal istikrar ve hedonik tüketim ile harcama sonrası suçluluk arasında kısmi aracı rolüne sahip olduğu söylenebilmektedir. Harcama eğilimi ile Duygusal istikrar ve Hedonik tüketim arasında pozitif bir ilişki olduğu, Ayrıca Hedonik tüketimin Finansal öz yetkinlik üzerindeki negatif etkisinden dolayı, Finansal öz yetkinliğin Harcama eğilimi üzerinde negatif bir mediator etkisi olduğu gözlemlenmiştir.

Tablo 11b. Model 2 Sonuçlan

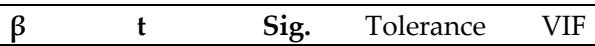

1. Adım

Bağımlı değişken: 'finansal öz yetkinlik'

Bağımsız

'duygusal

değişken:

\begin{tabular}{|c|c|c|c|}
\hline $\begin{array}{l}\text { auygusal } \\
\text { istikrar' }\end{array}$ & 0,244 & 6,102 & 0,000 \\
\hline 'hedonik & $-0,113$ & $-2,287$ & 0,005 \\
\hline
\end{tabular}

1,042

tüketim'

$\mathrm{F}=27,176$; Sig. $=0,000 ; \mathrm{R}$ kare $=0,084$; Düzeltilmiş $\mathrm{R}$ kare $=0,081$

\section{Adım}

Bağımlı değişken: 'Harcama sonrası

suçluluk'

Bağımsız

değişken:

\begin{tabular}{lllll} 
'duygusal istikrar' & $-0,177$ & $-4,892$ & 0,000 & 0,960 \\
\cline { 1 - 5 } & 0,434 & 11,972 & 0,000 &
\end{tabular}

F=99,396; Sig. $=0,000 ;$ R kare $=0,250$; Düzeltilmiş $R$ kare $=0,248$

\begin{tabular}{|c|c|c|c|c|c|c|}
\hline \multicolumn{2}{|c|}{$\begin{array}{l}\text { 3. Adım } \\
\text { Bağımlı değişken: 'Harcama sonrası } \\
\text { suçluluk' }\end{array}$} & \multirow[b]{2}{*}{$-0,088$} & \multirow[b]{2}{*}{$-2,565$} & \multirow[b]{2}{*}{0,011} & \multirow[b]{2}{*}{0,903} & \multirow[b]{2}{*}{1,107} \\
\hline \multirow{3}{*}{$\begin{array}{l}\text { Bağımsız } \\
\text { değişken: }\end{array}$} & 'duygusal istikrar' & & & & & \\
\hline & 'hedonik tüketim' & 0,392 & 11,753 & 0,000 & 0,947 & 1,056 \\
\hline & 'finansal öz yetkinlik' & $-0,366$ & $-10,799$ & 0,000 & 0,916 & 1,091 \\
\hline
\end{tabular}

Modeldeki bağımsız değişkenler arasında çoklu doğrusallık olup olmadığını tespit etmek için, tolerance ve VIF değerleri de raporlanmıştır. 
Tolerance değeri 0,10'dan büyük ve VIF değeri 10'dan küçük olduğundan bağımsız değişkenler arasında çoklu doğrusallık problemi olmadığına karar verilmiştir (Franke ,2010).

\section{Sonuç}

Literatürde alışveriş bağımlılığı incelendiğinde onlarca çalışmanın vardığı ortak sonuç şudur ki; bu kavramın tek faktörle açıklanması mümkün değildir; ve bu karmaşık yapılı davranış üzerinde etkili dinamikleri anlamak, geniş bir perspektifte ele alınan faktörlerin bir arada çözümlenmesiyle mümkündür. Alışveriş bağımlılı̆̆ konusu incelenirken yap1lan araştırma içerisinde de değinildiği üzere bir çok farklı değişkenle ilişkisi test edilerek çeşitli varsayımlarda bulunulmuştur. Yapılan bu çalışmada 'duygusal istikrar' ve 'hedonik tüketim' değişkenlerinin 'alı̧̧veriş bağımlılığı' üzerinde etkisi olduğu ve bu etkiye 'finansal öz yetkinlik' isimli değişkenin aracılık ettiği varsayılmaktadır.

D"e Astous (1990) yaptığ çalışmada, alışveriş bağımlılı̆̆ı eğiliminin yaşa, göre farklılaştığı hipotezini öne sürmüştür. Bulgulara göre; yaş ve alışveriş bağımlılığı arasında negatif bir ilişki saptanmıştır. Bu doğrultuda, kişi ne kadar genç ise, alışveriş bağımlılığı eğilimi görülme olasılığ1 o derece fazladır. Moschis ve Churchill (1978), yaş ile ilgili bu durumu, olgunlaşan bireylerin finansal konularda daha rasyonelleştiği ve sosyal kabul görmek adına tüketim kalıplarında değişikliğe daha seyrek gidilebileceği olarak açıklamıştır. Literatürde de değinilen pek çok çalışma, alışveriş bağımlılığı ve yaş arasında negatif bir bağlantı saptayarak, bu durumun özellikle gençler üzerinde yayılan bir sorun olduğuna dikkat çekmiştir (Kearney ve Stevens, 2012). Bu görüşe ek olarak, 18-24 yaş aralığındaki üniversite gençliğinin, alışveriş bağımlılığının tespiti için uygun demografik kriterleri sergilediğinden ideal bir örneklem oluşturduğu da düşünülmektedir (Kearney ve Stevens, 2012). Yapılan bu çalışma üniversite öğrencilerinden elde edilen verilere dayandırıldığı ve aynı yaş grubu içerisinde veriler toplandığı için yaş demografik değişkeni aynı aralıkta olması sebebi ile araştırma da dikkate alınmamıştır.

Kişiliğin boyutları arasında da geçen, duygusal istikrar çeşitli çalışmalarda alışveriş bağımlılı̆̆ıyla ilişkilendirilen öğelerdendir. Duygusal istikrar ile alışveriş bağımlılığı eğilimi arasındaki ilişkinin anlamlı çıkması, 
alışveriş bağımlılı̆̆ olan duygusal istikrarın önemli bir veri olabileceğine işaret etmektedir. $\mathrm{Bu}$ doğrultuda, duygusal anlamda daha dengeli olan bireyde alışveriş bağımlılığına karşı daha az eğilim gözlemlenmesi beklenmektedir. Alışveriş bağımlılığında, bireyin moralini düzeltmek, olumsuzluklardan kurtulma, yani duygulara yönelim esastır (Kang ve Johnson,2011; Luomola,2002). Benzer şekilde, düşük ve olumsuz ruh halinden kurtulmak ve geçici de olsa iyi hissetmek adına, alışverişe sarılan alışveriş bağımlıları, kendilerini ancak bir şeyler satın alarak iyi hissettiklerini ifade etmişlerdir (Ridgway ve diğerleri,2008). Hedonik tüketimde de benzer şekilde tüketiciyi motive eden duygular, öznel yargılar ve keyif arayışıdır. Bu bağlamda, hedonik tüketimin duygu dünyasındaki yarattığ dalgalanma, alışveriş bağımlılığı açısından da bir uyarıcı görevi üstlenebilir.

Cinsiyet ve alışveriş bağımlılığı arasındaki ilişkiye bakıldığında ilk yıllardaki çalışmalarda bağımlıların büyük ölçüde kadınlar olduğuna inanılmaktadır (Kearney ve Stevens, 2012), güncel çalışmalar da bunu destekler niteliktedir (Mueller ve diğerleri, 2007; Koran ve diğerleri, 2006; Ergin,2010). O'Guinn ve Faber (1989) de benzer şekilde kendini alışveriş bağımlısı olarak ifade eden bireylerin \%95 inin kadın olduğu sonucuna ulaşmıştır. De Astous (1990) da yaptığ1 çalışmada, alışveriş bağımlılığı eğiliminin cinsiyete göre farklılaştığı hipotezini, gerçekleştirdiği saha çalışmasıyla alışveriş bağımlılı̆̆ı genel puanları bakımından kadınların, erkeklerden daha fazla eğilimli olduğu yönünde kanıtlamıştır. Bu kanı pek çok çalışmaca desteklenmektedir (Mueller ve diğerleri, 2007; Koran ve diğerleri, 2006; Ergin,2010). Yapılan bu çalışma neticesinde de literatürü destekler şekilde kadın katılımcıların erkek katılımc1lara göre alışveriş bağımlılıklarının daha fazla olduğu görülmektedir.

Gelir seviyesi ve alışveriş bağımlılığı eğilimine ilişkin ise, literatürde çelişkili sonuçlar olsa da, genel fikir anlamlı bir ilişki olmadığı yönündedir. Yapılan bu çalışmanın analiz sonuçlarına göre gelir demografik değişkeni baz alındığında gelir durumu arttıkça katılımcıların alışveriş bağımlılıklarının da arttığını söylemek mümkündür.

Yapılan çalışmada 'duygusal istikrar' ve 'hedonik tüketim' değişkenleri bağımsız değişken, 'alışveriş bağımlılı̆̆ı' değişkeni bağımlı değişken, 'finansal öz yetkinlik' değişkeni ise aracı değişken rolündedir. 'Alışveriş bağımlılı̆̆ı' değişkeni yapılan faktör ve güvenilirlik analizi neticesinde 
literatürle de paralel olarak 'Harcama eğilimi' ve 'Harcama sonrası suçluluk' olmak üzere iki faktörle temsil edilmektedir. Dolayısıyla bu iki değişkenin tek tek bağımlı değişken rolünde olduğu iki ayrı model tahmin edilmiştir. Model-1'de 'Harcama eğilimi' değişkeni, Model-2' de ise 'Harcama sonrası suçluluk' değişkeni bağımlı değişken olarak ele alınmıştır. Model 1 sonuçlarına bakıldığında bağımsız değişkenlerin (duygusal istikrar ve hedonik tüketim) aracı değişken (finansal öz yetkinlik) üzerindeki etkisinin ve bağımsız değişkenlerin(duygusal istikrar ve hedonik tüketim) bağımlı değişken ('harcama eğilimi') üzerindeki etkisinin anlamlı olduğu görülmektedir. Duygusal istikrar, hedonik tüketim ve finansal öz yetkinlik değişkenleri 'harcama eğilimi' değişkenini kestirmek için birlikte modele dâhil edildiğinde, hedonik tüketim değişkeninin 'harcama eğilimi' değişkeni üzerindeki etkisinin azaldığı ve bu etkinin anlamlı olduğu görülmektedir. Buna göre finansal öz yetkinlik değişkeninin, hedonik tüketim ile 'harcama eğilimi' arasında kısmi aracı rolüne sahip olduğu söylenebilmektedir. Son adımda duygusal istikrar değişkeninin katsayısı anlamlı olmadığı için, finansal öz yetkinlik değişkeninin duygusal istikrar ile 'Harcama eğilimi' arasındaki aracılık etkisinden bahsedilemeyecektir.

Model 2 sonuçlarına bakıldığında yine bağımsız değişkenlerin (duygusal istikrar ve hedonik tüketim) aracı değişken (finansal öz yetkinlik) üzerindeki etkisinin anlamlı olduğu görülmektedir. Zira bağımsız değişkenler ve aracı değişken bir önceki model ile aynıdır. Ayrıca model 2' de bağımsız değişkenlerin (duygusal istikrar ve hedonik tüketim) bağımlı değişken ('harcama sonrası suçluluk') üzerindeki etkisinin de anlamlı olduğu görülmektedir. Son adımda duygusal istikrar, hedonik tüketim ve finansal öz yetkinlik değişkenleri 'harcama sonrası suçluluk' değişkenini kestirmek için birlikte modele dâhil edilmiştir.Bu adımda hem duygusal istikrar hem de hedonik tüketim değişkeninin 'harcama sonrası suçluluk' değişkeni üzerindeki etkisinin mutlak değerce azaldığı ve bu etkilerin anlamlı olduğu görülmektedir. Buna göre finansal öz-yetkinlik değişkeninin, duygusal istikrar ve hedonik tüketim ile 'harcama eğilimi' arasında kısmi aracı rolüne sahip olduğu söylenmektedir. 


\title{
EXTENDED ABSTRACT
}

\section{The Role of Financial Self-Efficacy in the Effect of Hedonistic Tendencies and Emotional Stability on Shopping Addiction of University Students}

\author{
Esra Özkan Pir \\ Erzincan Binali Yildırım University
}

One of the important objectives of marketing discipline is to analyze the purchasing process of the individual in all its dimensions. The point of view of the concept of buying and shopping, which emerges from the absolute dominance of rationality, has changed over time. In the past, the need to buy the individual was the reason, but nowadays, these motives have turned into emotional-intensive concepts such as desire, entertainment and experience. Thus, the discipline of consumer behavior, which generally operates in society and examines the purchase behavior thought to be exemplary, has also made understanding of the individual holistic by investigating certain forms of purchasing behavior that deviate from normality and can be considered excessive.

When the literature after the 1980s was examined, especially between 1996-2004, the phenomenon of purchase dependence within the scope of abnormal purchasing behavior is the subject of academic publications (Dittmar,2004, p.431). When we look at purchasing dependence from a broad framework, it is seen that this issue is examined under the title of exceptional behaviors related to consumption such as reactive consumption and over consumption. While some researchers define these consumption behaviors as compulsive disorder, another group defines it as addiction. The compulsive approach generally relates to the process by which unimpeded impulses cause the individual to act involuntarily. Addiction is defined as the normal behavior of a person as a pathological habit (Desmond, 2003, p.392). When the literature is examined, we see that shopping addiction and purchasing addiction can be used interchangeably. It should be noted, however, that the purchase of a product / service is not required, even though the purchase usually 
ends with the purchase. Shopping has become a part of everyday life, a ritual for the current consumer. Even if the consumer does not buy anything, the time spent by the consumer in the shopping environment does not change the fact of the knowledge / experience or feelings they have experienced. Accordingly, instead of purchasing addiction, the term shopping addiction can be used.

The three main components of shopping addiction, this extreme behavior, which is emphasized in the world of marketing and psychology; the desire to purchase which cannot be prevented by the consumer, the loss of control during the purchasing process and the continuation of the purchase despite the social, professional and financial problems experienced (Dittmar vd., 2007).

Generally, products are purchased to meet individual requirements and increase personal satisfaction. However, unlimited purchase involving unrestricted impulse buying can destroy individuals, families and communities (Sohn and Choi, 2014, p.244). Compulsive buying disorder (oniomania) is a serious problem that is increasing day by day. As the consumer market is constantly evolving, traders are increasingly focused on ways that can affect the way consumers buy more. These discounts, promotional packages, bonuses, loyalty awards and so on. can be done with (Simion, 2018, p.2).

While the decision-making process of the consumer is perceived as rational in the economy, it is determined that emotions and feelings are influential in this process by believing that this mechanism cannot be explained with mere rationality in marketing studies, especially after 1980 's. The concept of hedonic consumption in marketing literature was first introduced by Hirschman and Holbrook in 1982. The authors highlighted the importance of the impact of these abstract values on purchasing and expressed the elements that direct the individual's experience of consumption as senses, fantasy world and emotions, that is, hedonic elements (Hirschman and Holbrook, 1982, p.94).

In order to adhere to the main purpose of the study, the Emotional Stability dimension, which is thought to have an effect on the situations such as activating the individual and reaching the emotional goals, was examined while analyzing shopping addiction. At the same time, the most concrete and sanctioned result of shopping addiction is the finan- 
cial difficulty that drives the person. This overpurchase, which one cannot prevent, often results in financial indebtedness and bankruptcy (Edwards, 1994, p.86). In the study, it is assumed that the effect of financial stability and hedonic consumption variables on shopping dependence is mediated by financial self-efficacy variable.

The main purpose of this study was to investigate the factors such as hedonistic tendencies, emotional stability and financial self-efficacy of individuals thought to have an impact on shopping addiction, which enabled a strong and deviant concept such as addiction to be explained from different perspectives. In the study, while the factors affecting the shopping addiction were considered, the financial self-efficacy of the individuals was accepted as the mediating variable. In this direction, the study consists of four main sections. In the first part, the introductory part, the purpose and scope of the research is explained by giving brief information about the subject. In the second part, conceptual framework, definitions of shopping addiction, hedonistic tendency, emotional stability, financial self-efficacy are explained in detail. In the third part, the methods which are used to measure the mediating effect of financial selfefficacy on the effects of hedonistic tendency and emotional stability on shopping dependencies of university students are presented. In the fourth part of the research, the findings obtained as a result of the analyzes are given.

In order to carry out this research, a questionnaire was applied to 598 students studying at Binali Y1ldırım University in Erzincan. The data obtained from the survey were analyzed using SPSS package program and the results were interpreted. As a result of the study, it was found that female participants had more shopping addictions than male participants, as the income level increased, shopping addictions of the participants increased and emotional stability and hedonic consumption variables had an effect on shopping addiction and this effect was mediated by financial self-efficacy.

\section{Kaynakça / References}

Arnold, M. J., ve Reynolds, K. E. (2003).Hedonic shoppingmotivations. Journal of retailing, 79(2), 77-95. 
Atkinson, J.W. (1987). Strength of motivation and efficiency of performance. In J.W Atkinson \& J.O. Raynor (Eds), Motivation and Achievement (p.117-42). New York: Winston

Babin B., Darden W. ve Griffin M. (1994). Work and/or fun: measuringhedonic and utilitarian shopping value, Journal of Consumer Research, 20(4), 644-656.

Bandura, A. (1977). Self-efficacy: toward a unifying theory of behavioral change. Psychological review, 84(2), 191.

Bandura, A. (1986). Social foundations of thought and action. Englewood Cliffs, NJ, 1986.

Bandura, A. (1997). Self-efficacy: The exercise of control. Macmillan.

Baudrıllard, J. (2010). Tüketim Toplumu,Ayrıntı Yayınları, 4.Basım, İstanbul.

Black, D.W. (2001). Compulsive Buying disorder: Definition, assessment, epidemiology and clinical management. CNS Drugs, 15, 17-27.

Bleidorn, W., Klimstra, T. A., Denissen, J. J., Rentfrow, P. J., Potter, J., ve Gosling, S. D. (2013). Personality maturation around the world: A crosscultural examination of social-investmenttheory. Psychological Science, 24(12), 2530-2540.

Bowen, C. F. (1995). Teen and parent perceptions of informal money management education. In Proceedings of the1995 Annual Conference of the Association for Financial Counseling and Planning (p. 77).

Broekhuizen, T. L. (2006). Understanding channel purchase intentions: measuring online and offline shopping value perceptions. Ridderkerk: Labyrinth Publications.

Cheng, H., ve Furnham, A. (2016). The big-five personality traits, maternal smoking during pregnancy, and educational qualifications as predictors of tobacco use in a nationally representative sample. PloS one, 11(1), 1-10.

Chinomona, R. (2013). An empirical examination of the predictors of consumer compulsive buying as an" impulse control disorder not otherwise specified": A branding perspective. Journal of Applied Business Research, 29(6), 1689-1704.

D' Astous, A. ve Tremblay, S. (1989). The compulsive side of normal consumers: an empirical study. In G.J., Papavasiliou, N.K. ve Kouremenos, A.G. (Editörlügünde), Marketing Thought and Practice in the 1990s, Vol .1, The Athens School of Economics and Business Science, Athens. 
Danes, S. M. (1994). Parental perceptions of children's financial socialization. Financial Counseling and Planning, 5(1), 27-146.

Dittmar, H. (2005). Compulsive buying-a growing concern? An examination of gender, age, and endorsement of materialistic values as predictors. British Journal of Psychology, 96(4), 467-491.

Dittmar, H., Long,K. Ve Bond,R. (2007). When a better self is only a button clickaway: Associations between materialistic values, emotional and 1dentity-related buying motives, and compulsive buying tendency online. Journal of Social and Clinical Psychology, 26(3), 334-361.

Edwards, E. A. (1994). Development and test of a theory of compulsive buying. Ypsilanti: Eastern Michigan University.

Faber, R. J. ve O'Guinn, T.C. (1989). Classifying Compulsive Consumers: Advances in the Development of a Diagnostic Tool, In Advances in Consumer Research, Vol. 16, (p.738-744.)Srull, Thomas ed. Provo, UT: Association for Consumer Research,

Faber, R. J., ve O'Guinn, T. C. (1992). A clinical screener for compulsive buying. Journal of Consumer Research, 19, 459-469.

Faber, R.J. ve O'Guinn, T.C. (1988). Compulsive consumption and credit abuse. Journal of Consumer Policy, 77 (1 ), 97-109.

Flores, C. (2014). First generation college student financial literacy: Impact of self-efficacy and behavior.

Franke, G. R. (2010). Multicollinearity. Wiley International Encyclopedia of Marketing.

Goldberg, L.R. (1993). The structure of phenotypic personality traits, American Psychologlist,48, 26-34.

Hartston, H. (2012). The case for compulsive shopping as an addiction. Journal of psychoactive drugs, 44(1), 64-67.

Hausman, A. (2000). A multi-method investigation of consumer motivations in impulse buying behavior. Journal of consumer marketing, 17(5), 403426.

Heath, C., ve Soll, J. B. (1996). Mental budgeting and consumer decisions. Journal of consumer research, 23(1), 40-52.

Heckman, S. J., ve Grable, J. E. (2011). Testing the role of parental debt attitudes, student income, dependency status, and financial knowledge have in shaping financial self-efficacy among college students. College Student Journal, 45(1), 51-65. 
Hibbert, J. R., Beutler, I. F., ve Martin, T. M. (2004). Teacher versus parent influence on financial efficacy and behavior. In Proceedings of the 2004 Annual Conference of the Association of Financial Counseling and Planning (pp. 51-59).

Hirschman E. C. (1992). The consciousness of addiction: toward ageneral theory of compulsive consumption. Journal of Consumer Research, 19(2), 155-179.

Hirschman, E. C., ve Holbrook, M. B. (1982). Hedonic consumption: emerging concepts, methods and propositions. Journal of marketing, 46(3), 92-101.

Hirsh, S.K. ve Kummerow, J.M. (1990). Introduction to type in organizations, 2nd ed. Palo Alto, CA: Consulting Psycoholgists Press.

Hwang, J. Y., Shin, Y. C., Lim, S. W., Park, H. Y., Shin, N. Y., Jang, J. H., ve Kwon, J. S. (2012). Multidimensional comparison of personality characteristics of the Big Five model, impulsiveness, and affect in pathological gambling and obsessive-compulsive disorder. Journal of Gambling Studies, 28(3), 351-362.

Ikeda, S., Mizuno-Matsumoto, Y., Canuet, L., Ishii, R., Aoki, Y., Hata, M., ve Asakawa, T. (2015). Emotion regulation of neuroticism: emotional information processing related to psychosomatic state evaluated by electroencephalography and exact low-resolution brain electromagnetic tomography. Neuropsychobiology, 71(1), 34-41.

Johnson, T. ve Attman J. (2009). Compulsive buying in a product specific context: clothing, Journal of Fashion Marketing and management, 13(3), 394-405.

Jylhä, P., ve Isometsä, E. (2006). The relationship of neuroticism and extraversion to symptoms of anxiety and depression in the general population. Depression and anxiety, 23(5), 281-289.

Kasser, T. E., ve Kanner, A. D. (2004). Psychology and consumer culture: The struggle for a good life in a materialistic world. American Psychological Association.

Kearney, M. ve Stevens, L. (2012) Compulsive buying:Literature review and suggestions for future research. The Marketing Review, 12 (3), 233-251.

Kyrios, M., Frost, R. O. ve Steketee, G. (2004). Cognitions in compulsive buying and acquisition.Cognitive Therapy and Research, 28, 241-258. 
Lo, H.-Y. ve Harvey, N. (2011). Shopping without pain: Compulsive buying and the effects of credit card availability in Europe and the Far East. Journal of Economic Psychology, 32(1), 79.

Lown, J. (2011). Development and validation of a financial self-efficacy scale. Journal of Financial Counseling and Planning, 22, 54-63.

McElroy, S., Keck, R, Pope, H., Smith, J. ve Strakowski, S. (1994). Compulsive buying: A report of 20 cases. Journal of Clinical Psychiatry, 55(6), 242248.

Mikołajczak-Degrauwe, K., Brengman, M., Wauters, B., ve Rossi, G. (2012). Does personality affect compulsive buying? An application of the big five personality model. In Psychology-Selected Papers. IntechOpen.

Morris, M. B., Burns, G. N., Periard, D. A., ve Shoda, E. A. (2015). Extraversion-emotional stability circumplex traits and subjective wellbeing. Journal of Happiness Studies, 16(6), 1509-1523.

Mowen, J. C. ve Spears, N. (1999). Understanding compulsive buying among college students: A hierarchical approach. Journal of Consumer Psychology, 8(4), 407-430.

Myers, I.B. ve McCaulley, M.H. (1985). Manual: A guide to the development and use of the Myres-Briggs type indicator. Palo Alto, CA: ConsultingPsychologists Press.

Myers, İ.B. ve Meyers, P.B. (1984). Grifts differing, Palo Alto, CA: Consulting Psychologists Press.

O'Guinn, T. C., ve Faber, R. J. (1989). Compulsive buying: A phenomenological exploration. Journal of Consumer Research, 16, 147-157.

Palan, K.M., Morrow, P.C. ve Trapp, A. (2011). Compulsive Buying Behavior in College Students: The Mediating Role of Credit Card Misuse. The Journal of Marketing Theory and Practice, 19(1), 81-96.

Parrotta, J. L.,ve Johnson, P. J. (1998). The impact of financial attitudes and knowledge on financial management and satisfaction of recently married individuals. Journal of Financial Counseling and Planning, 9(2), 59.

Paulus, D. J., Vanwoerden, S., Norton, P. J., ve Sharp, C. (2016). Emotion dysregulation, psychological inflexibility, and shame as explanatory factors between neuroticism and depression. Journal of affective disorders, 190, 376-385.

Rao, V. (2013). Compulsive buying tendencies in normal consumers: The Indian experience. Journal of Management, 10 (1), 1-19. 
Ridgway, N.M., Kukar-Kinney, M. ve Monroe, K.M. (2008). An expanded conceptualization and new measure of compulsive buying, Journal of Consumer Research,35 (4), 622-639.

Roberts, J. A.,ve Martinez, C. R. (1998). The emerging consumer culture in Mexico: An exploratory investigation of compulsive buying in Mexican young adults. Journal of International Consumer Marketing, 10(1-2), 7-31.

Rook, D. W., ve Fisher, R. J. (1995). Normative influences on impulsive buying behavior. Journal of consumer research, 22(3), 305-313.

Saleem, S., Abideen,Z. ve Latif,A. (2010). Few Determinants of CompulsiveBuying of Youth in Pakistan, European Journal of Social Sciences,17(4), 1-19.

Schwarzer, R. ve Jerusalem, M. (1995, ). Generalized self-efficacy scale. In J. Weinman, S. Wright ve M. Johnston (Eds.), Measures in health psychology: A user's portfolio. Causal and control beliefs, (p.35-37). Windsor, , England: NFERNelson.

Simion, I. (2018). Shopping addiction. Romanian Journal of Cognitive Behavioral Therapy and Hypnosis, 5(1-8), 20-31.

Sohn, S. H.,ve Choi, Y. J. (2014). Phases of shopping addiction evidenced by experiences of compulsive buyers. International Journal of Mental Health and Addiction, 12(3), 243-254.

Sprotles, G. B.,ve Kendall, E. L. (1986). A methodology for profiling consumers' decision-making styles. Journal of Consumer Affairs, 20(2), 267279.

Tauber, E. M. (1972). Marketing notes and communications: Why do people shop?. Journal of marketing, 36(4), 46-49.

Torlak, Ö. (2000). Tüketim: Bireysel eylemin toplumsal dönüşümü. İnkılab Yayınları.

Valence, G., D“Astous,A ve Fortier, L. (1988) Compulsive buying: Concept and measurement. Journal of consumer policy, 11(September), 419-433.

Wood, D., ve Denissen, J. J. (2015). A functional perspective on personality trait development. Psychology of change: Life contexts, experiences, and identities, 97-115.

Yılmaz, F. (2018). Çağrı Merkezi Çalişanlarinda Duygusal Zekânın Örgütsel Özdeşleşme Üzerindeki Etkileri. Akademik Bakış, 67, 73-85. 
Yılmaz, F. (2019). Hangi Kişilik Özelliği Örgütsel Yaratıcıllk Üzerinde Daha Etkilidir?. Uluslararası Toplum Araştırmaları Dergisi,12(18), 167192.

Yükselen, C. (2003). Pazarlama; Illkeler ve yönetim. Detay Yayıncılık, Ankara.

\section{Kaynakça Bilgisi / Citation Information}

Özkan-Pir, E. (2019). Üniversite öğrencilerinin hedonistik eğilimleri ve duygusal istikrarlılıklarının alışveriş bağımlılıklarına etkisinde finansal öz yetkinliklerinin rolü. OPUS-Uluslararası Toplum Araştırmaları Dergisi, 13(19), 815-851. DOI: 10.26466/opus.588082. 